\title{
COMPARATIVE ANALYSIS OF SERUM CALCIUM AND MAGNESIUM AS A BETTER PREDICTOR IN CASES OF MILD AND SEVERE PRE-ECLAMPSIA.
}

\footnotetext{
1. MBBS, FCPS

Assistant Professor Pathology

QAMC, Bahawalpur.

2. MBBS, Ph.D

Associate Professor Physiology QAMC, Bahawalpur.

3. $3^{\text {rd }}$ Year Medical Student QAMC, Bahawalpur.

4. MBBS, FCPS

Assistant Professor Pathology Sheikh Zayed Medical College, Rahim Yar Khan.

5. MBBS, FCPS

Assistant Professor Gynecology and Obstetrics

Unit 1, Bahawal Victoria Hospital, Bahawalpur.

6. MBBS, FCPS

Assistant Professor Gynecology and

Obstetrics

Civil Hospital, Bahawalpur.
}

Correspondence Address:

Dr. Farheen Aslam

Assistant Professor Pathology

QAMC, Bahawalpur.

farheenaslam75@yahoo.com

Article received on:

08/10/2019

Accepted for publication:

05/03/2020
Farheen Aslam1, Irum Hayat ${ }^{2}$, Faizan Ahmad Zakir³, S. Sabahat Haider ${ }^{4}$, Shams-Un- Nisa ${ }^{5}$, Sadaf Un Nisa ${ }^{6}$

ABSTRACT... Objectives: The hypertensive disorders of pregnancy (HDP), especially severe preeclampsia are most common cause of neonatal and maternal mortality and morbidity. Alteration in metabolism of calcium and magnesium during pregnancy is considered to be one of etiological factor for pre-elampsia. Study Design: Case-control study. Settings: Departments of Pathology and Gynecology and Obstetrics, Bahawal Victoria Hospital. Period: September 2018 to June 2019. Material \& Methods: To compare whether serum levels of calcium or magnesium showed significant change in mild and severe preeclamptic patients as compared to control group. Research population consisted of pregnant females that were divided into three groups. The mild and severe preeclamptic groups comprised of 55 and 26 participants respectively and 45 were included in control group. The serum calcium and magnesium levels were measured in these groups. Results: Maximum numbers of preeclamptic cases were presented at 28-32 week of gestation while severe pre-eclamptic group showed most cases in 33-36 weeks. In both groups, most of cases occurred in multiparous women as compared to nulliparous women. The normotensive group showed serum calcium and magnesium levels of $9.08 \pm 0.63$ and $2.12 \pm 0.22 \mathrm{mg} / \mathrm{dl}$ while mild preeclamptic (mPE) had mean value of $7.91 \pm 0.64$ and $1.58 \pm 0.42 \mathrm{mg} / \mathrm{dl}$ and measurement were $7.67 \pm 0.48$ and $1.26 \pm 0.44$ in cases of severe pre eclampsia (sPE). Serum magnesium levels were significantly lower in SPE as compared to $\mathrm{mPE}(<0.0001)$ while difference was not statistically significant for serum calcium level $(0.14)$. Conclusion: Both decrease level of serum calcium and magnesium might be risk factor in development of preeclampsia with more emphasis on role of low magnesium as a prognostic marker in severe preeclamptic cases.

Key words: $\quad$ Magnesium, Mild and Severe Pre-Eclampsia, Serum Calcium.

Article Citation: Aslam F, Hayat I, Zakir FA, Haider SS, Shams Un Nisa, Sadaf Un Nisa. Comparative analysis of serum calcium and magnesium as a better predictor in cases of mild and severe pre-eclampsia. Professional Med J 2020; 27(8):1722-1727. DOI: 10.29309/TPMJ/2020.27.08.4228

\section{INTRODUCTION}

The hypertensive disorders of pregnancy (HDP), specially preeclampsia and eclampsia are most common cause of neonatal and maternal mortality and morbidity. ${ }^{1}$ Preeclampsia, presents with hypertension, proteinuria and edema can progress to serious and devastating complication; eclampsia which manifest itself with seizures. It can also lead to renal and respiratory dysfunction, HELPP syndrome, stroke and cardiac failure. ${ }^{2}$ In order to save the life of preeclamptic mother, premature delivery of compromised fetus has to be performed that is responsible for perinatal mortality and motility. ${ }^{3}$ The landscape analysis of data showed that burden of maternal death due to HPD is $9 \%$ in developing countries and $16 \%$ in developed countries and every year $4-18 \%$ cases of preeclampsia are recorded globally. ${ }^{4}$

Current evidence suggests that the endothelial dysfunction seen in preeclamptic pregnant women may persist years after the episode and therefore these women may be at high risk of cardiovascular diseases later in life. ${ }^{5}$

Magnesium is a mineral that is crucial part of many neurological, reproductive, cardiovascular and immune processes occurring in the body. The literature has also suggested the role of magnesium in regulation of blood pressure as it influence tone and contractility of smooth muscles of blood vessels. ${ }^{6}$ Calcium has a definitive role 
in neuro muscular excitability, vascular and smooth muscle contraction, clotting mechanism. It has also essential function in formation and secretion of various enzymes and hormones. The hypocalcaemia increases susceptibility for tetany, cerebral hemorrhage, rickets and osteomalacia. ${ }^{7}$

The diet of women of developing countries is deficient in essential minerals and vitamins as financial resources are limited so they are unable to cope with increase demand of growing fetus. If low level of calcium and magnesium are involved in pathogenesis of preeclampsia, then simple fortification of diet with these minerals can solve the problem. ${ }^{8}$

But previous studies have revealed disparity in outcome between the relationship of these two minerals and pre eclampsia. Some studies agreed with role of both elements but some put emphasis on the role of magnesium and other give importance to calcium. ${ }^{9,10,11}$

Alteration in metabolism of calcium and magnesium during pregnancy is considered to be one of etiological factor for preelampsia and it is proposed that in developing countries like Pakistan, females in their reproductive years particularly in pregnancy are prone to micro and macro nutrient insufficiency due to increase demand of growing fetus and poor body reserves.

Since both these elements have significant role in maintaining the blood pressure, the present study was conducted to compare whether serum levels of calcium or magnesium showed significant change in mild and severe preeclamptic patients as compared to control group.

\section{MATERIAL \& METHODS}

After approval from ethical committee, this study was carried out in Pathology and Obstetrics and Gynecology Departments of Quaid-e-Azam Medical College and Bahawal Victoria Hospital (BVH) Bahawalpur from December 2018 to June 2019. The Participants were inducted from outpatient department and labor room of $\mathrm{BVH}$. Research population included 74 pregnant mild and severe pre eclamptic women and 45 control groups, were selected by the purposive sampling method. Blood pressure (BP) more than $140 / 90$ and proteinuria $>300 \mathrm{mg} / 24 \mathrm{hr}$ urine sample or $1+$ on dipstick were used to define mild Pre eclamptic group while for selection of severe PE, we consider if one of the following features were present; Blood pressure > $160 / 110$, proteinuria $>3 \mathrm{~g} / 24 \mathrm{hr}$ urine or dip $3+$ in dipstick two consecutive urine samples within $4 \mathrm{hr}$, urine volume $<500 \mathrm{ml} / 24 \mathrm{hr}$, epigastric pain with hemolysis, thrombocytopenia and raised hepatic enzyme levels, persistent neurologic symptoms or headache, blurring of vision and seizures. The pregnant women with a history of chronic hypertension, cardiovascular or kidney lesion, any form of diabetes or using calcium and magnesium supplements were excluded from the clinical group. $5 \mathrm{ml}$ of venous blood was drawn from antecubital vein of each participant in clot activator tube. Samples were centrifuged at $3000 \mathrm{rpm}$ for 5 minutes. Serum calcium was measured by $\mathrm{O}$ Cresolphthalein (OCP) while magnesium was estimated by Xylidl Blue method on fully automated chemistry analyzer AU680. The urinary protein, LFTs and RFTs were also performed on AU 680.The intra-assay and interassay coefficient of variance of serum magnesium was $0.9 \%$ and $1.08 \%$ and calcium was $0.62 \%$ and $0.89 \%$, respectively.

The SPSS software package version 20.0 was used for analysis of data and expressed in terms of mean, standard deviation (SD) and percentage. The ANOVA was used to compare continuous variables. $P$ value of $<0.05$ was considered to be statistically significant.

\section{RESULTS}

Average gestational age for the mild preeclamptic group was $30.4 \pm 3.36,34.2 \pm 4.60$ for severe group and $33.7 \pm 4.36$ for control group. Demographic parameters of each group were presented in Table-I.

Maximum numbers of preeclamptic cases were presented at 28-32 week of gestation while severe pre-eclamptic group showed most cases in 33-36 weeks. In both groups, most of cases occurred in multiparous women as compared to nulliparous 
women. The analysis of one way ANOVA showed that systolic and diastolic BP had significant difference of $p<0.001$ among three groups as shown in Table-Il.

In case of serum calcium, the levels decreased from normotensive $(9.08 \pm 0.63 \mathrm{mg} / \mathrm{dl})$ to the two pre-eclamptic group as shown in Figure-1 but this reduction in concentration $(7.91 \pm 0.64$ vs $7.67 \pm 0.48$ ) between mild and severe preeeclamptic groups (difference of means 0.23 , $95 \%$ confidence interval 0.04 to 0.52 )was not statistically significant ( $p=0.13$ ) (Table-II) while decrease in values of serum magnesium was observed among three groups (Figure-2) with control group had levels of $2.12 \pm 0.22 \mathrm{mg} / \mathrm{dl}$ while notable difference between two risk groups $(1.58 \pm 0.42$ vs $1.26 \pm 0.44)$ was observed that was highly significant (difference of means $0.31,95 \%$ confidence interval 0.14 to 0.40 ).

\begin{tabular}{|c|c|c|c|}
\hline & Control Group $(\mathrm{N}=40)$ & $\mathrm{mPE}(\mathrm{N}=55)$ & SPE $(N=26)$ \\
\hline $\begin{array}{l}\text { Age (years) } \\
<20 \\
20-35 \\
>35\end{array}$ & $\begin{array}{l}12 \\
14 \\
14\end{array}$ & $\begin{array}{l}18 \\
14 \\
23\end{array}$ & $\begin{array}{c}8 \\
7 \\
11\end{array}$ \\
\hline $\begin{array}{l}\text { Gestational week } \\
28-32 \\
33-36 \\
>36\end{array}$ & $\begin{array}{l}16 \\
11 \\
13\end{array}$ & $\begin{array}{l}25 \\
17 \\
13\end{array}$ & $\begin{array}{c}4 \\
11 \\
7\end{array}$ \\
\hline $\begin{array}{l}\text { Parity } \\
0 \\
1-3 \\
>3\end{array}$ & $\begin{array}{l}15 \\
08 \\
17\end{array}$ & $\begin{array}{l}19 \\
14 \\
22\end{array}$ & $\begin{array}{l}08 \\
06 \\
12\end{array}$ \\
\hline
\end{tabular}

Table-I. Data comparison for age, gestational week and parity.

\begin{tabular}{|c|c|c|c|}
\hline Parameters & Normotensive & mPE & Spe \\
\hline Serum Calcium $\ddagger$ (mg/dl) & $9.08 \pm 0.63$ & $7.91 \pm 0.64$ & $7.67 \pm 0.48$ \\
\hline Serum Magnesium** (mg/dl) & $2.12 \pm 0.22$ & $1.58 \pm 0.42$ & $1.26 \pm 0.44$ \\
\hline Systolic Blood Pressure $(\mathrm{mmHg})($ & $103.26 \pm 9.93$ & $161.7 \pm 17.03$ & $193.0 \pm 29.76$ \\
\hline Diastolic Blood Pressure $(\mathrm{mmHg}) \neq$ & $71.66 \pm 8.38$ & $97.95 \pm 8.54$ & $117.53 \pm 17.6$ \\
\hline
\end{tabular}

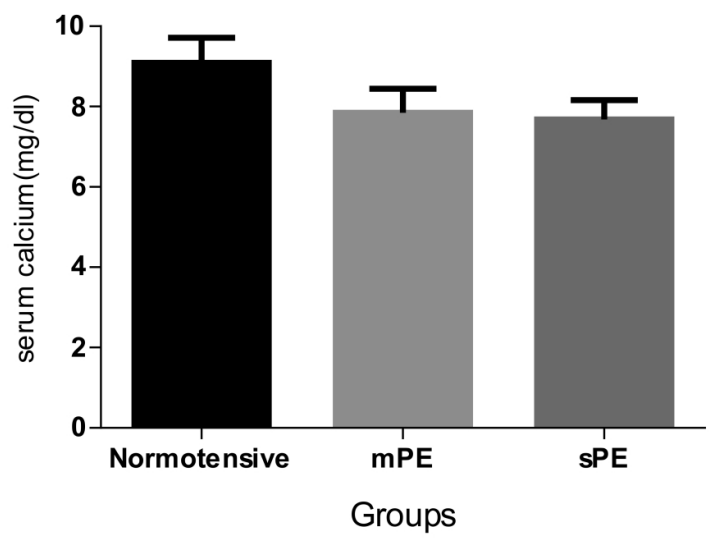

Fig-1: Comparison of three groups for serum calcium

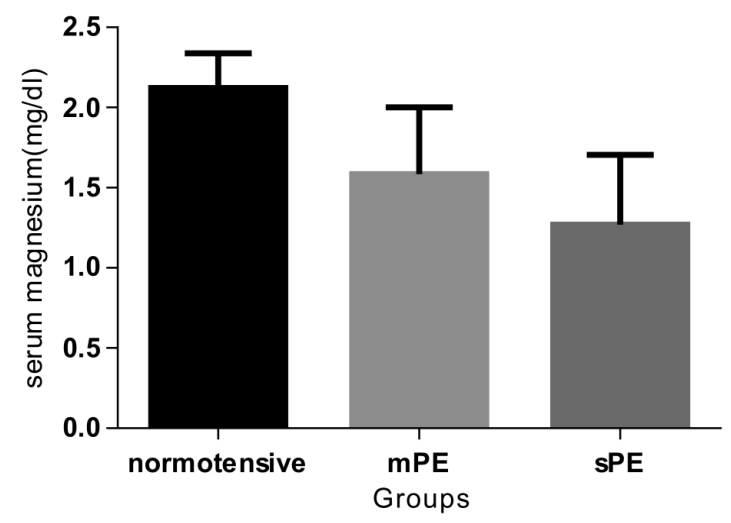

Fig-2: Comparison of three groups for serum Magnesiu $\mathbf{m}$ 
Age, parity and gestational age among three group were not significantly different $(P<0.05)$. In severe preeclampsia group, 09 presented with BP >160/110, 06 had imminent eclampsia, 04 with eclampsia, 05 had proteinuria of $>3 \mathrm{gram} / 24$ hour and 02 with HELLP syndrome. The females of age more than 35 years made the largest group of the three and multiparous women were more affected with this condition. The mean systolic blood pressure for mild and severe groups were161.7 \pm 17.03 and 193.0 \pm 29.76 and diastolic BP of two groups were $97.95 \pm 8.54$ and $117.53 \pm 17.6$.

\section{DISCUSSION}

Preeclampsia is one of the commonest and catastrophic obstetrical complications of pregnancy in developing countries. In spite of several studies on this condition, its exact etiology is not clearly interpreted yet. Studies have observed that alteration in values of serum calcium and magnesium in preeclampsia could be responsible in pathophysiology of preeclampsia. $^{12}$

It is hypothesized that this multifactorial disease might be due to increases synthesis of free radicals from enhanced oxidative stress and decrease serum levels of those elements that play a vital role in synthesis of materials necessary for immune response of the body. Though various novel markers i,e serum placental growth factor (PIGF), soluble fms-like tyrosine kinase 1 and soluble endoglin have been discovered that can serve as early predictor of preeclampsia. ${ }^{13,14}$ Nevertheless, serum calcium and magnesium may be practical and cost-effective predictors for preeclampsia since the start of pregnancy. ${ }^{15}$

The present study showed that in comparison to control group, mean serum calcium level was significantly reduced $(p<0.001)$ in both mild and severe preeclamptic groups. The outcome of our result was in accordance with earlier reports ${ }^{16,17}$ with difference that there was no statistically significant difference between mild and severe preeclamptic group. The pregnant mother needs 30-50 gram of calcium to fulfill the requirement of growing fetus and to support her reserves for lactation. The maximum transport of calcium occurs in third trimester where upto $350 \mathrm{mg}$ of this mineral is transferred to fetus via uteroplacental route in $35^{\text {th }}$ gestational week. In pregnancy, the increase plasma volume leads to concomitant hemodilution state and results in dilution of all plasma constituents including calcium and magnesium. As pregnancy advances there is more pronounced hypercalciuria due to enhance renal plasma flow and glomerular filtration rate. So in response to this hypocalcemic effect, there is increase synthesis of paratharmone $(\mathrm{PTH})$ that raise intracellular calcium level in vascular smooth muscle and have vasoconstriction effect. This process increases vascular resistance of arteries and arterioles that might result in hypertension in preeclamptic mother. ${ }^{18,19}$

Our study revealed that there was significant difference in serum magnesium level between control and two high risk groups. Moreover its levels are statistically different in mild and severe preeclampsia and might be used to predict those mild cases that can suffer from complications of this disease. Previous studies by Al-Jameil ${ }^{10}$ and Deshpande ${ }^{20}$ also demonstrated that serum magnesium decreased as pregnancy advanced in comparison to normal pregnant group. But the study performed on Sudanese women showed increase level of serum magnesium in preeclamptic females when analysis was done on atomic absorption spectrophotometry. ${ }^{21}$ But other study failed to determine any difference between two groups. ${ }^{22}$

Serum Mg increases excitability of cardiac muscles and contributes significantly to maintain tone and contractility of smooth muscle of blood vessels pressure. Increase in blood pressure may be due to decrease vasodilating action of serum magnesium. It serves as a calcium channel blocking agent and restrict the calcium mediated vasoconstriction of smooth that is responsible of vasodilation of arteries and decreases blood pressure. Hypomagnesaemia hampers the depolarization - repolarization process leading to raise intracellular calcium via opening of calcium channel s of cell membrane and increasing blood pressure. ${ }^{22,23}$ Further it has been postulated that 
hypomagnesaemia promotes vasoconstriction roles of nor adrenergic and angiotensin $11 .{ }^{20}$ It also liberates endothelin-1 from endothelial cells that induces vasoconstriction and restricts prostacyclin mediated vasodilation of blood vasculature especially from the umbilical arteries that further augments the blood pressure of preeclamptic mother. ${ }^{24}$ Thus, the defective function of membrane channels resulting in reduction in intracellular magnesium levels might have pivotal contribution in vasoconstriction process.

The disparity in results of these researches may be due to use of different analytical techniques and instruments or it may be attributed due to geographical and genetic variability of subjects and alteration in dietary practices and socioeconomic conditions of study population.

\section{CONCLUSION}

Our study concluded that both serum calcium and magnesium should be evaluated routinely besides other lab investigation for early detection of preeclampsia and more emphasis should be given to serum magnesium level to monitor its progression to devastating high risk condition i,e severe preeclampsia.

Copyright@ 05 Mar, 2020.

\section{REFERENCES}

1. Soydemir F, Kenny L. Hypertension in pregnancy. Current Obstet Gynaecol. 2006; 16:315-20.

2. Janani $F$, Changaee $F$. Seasonal variation in the prevalence of preeclampsia. J Family Med Prim Care. 2017 Oct-Dec; 6(4):766-9.

3. Porreco RP, Barkey R. Peripartum intensive care. J Matern Fetal Neonatal Med. 2010 Oct; 23(10):1136-8.

4. Jeyabalan A. Epidemiology of preeclampsia: Impact of obesity. Nutr Rev. 2013; 71 Suppl 1(0 1):S18-S25.

5. Sibai BM. Diagnosis and management of gestational hypertension and preeclampsia. Obstet Gynecol. 2003; 102(1):181-92.

6. Shahid AR, Hosna AU, Tahmina HZ. Hypomagnesaemia in pregnancy: A predictor of preterm labour. J Dhaka Med Coll 2010; 19:51-7.
7. Zemel MB. Calcium modulation of hypertension and obesity: Mechanisms and implications. J Am Coll Nutr. 2001 Oct; 20(5 Suppl):428S-435S; discussion 440S-442S.

8. Jain, S., Sharma P, Kulshreshtha S, Mohan G, Singh $S$. The Role of calcium, magnesium and zinc in preeclampsia. Biol Trace Elem Res. 2010 Feb; 133(2):162-70.

9. Al-Jameil N, Tabassum H, Ali MN, Qadeer MA, Khan FA, Al-Rashed M. Correlation between serum trace elements and risk of preeclampsia: A case controlled study in Riyadh, Saudi Arabia. Saudi J Biol Sci. 2017 Sep; 24(6):1142-8.

10. Enaruna NO, Ande A, Okpere EE. Clinical significance of low serum magnesium in pregnant women attending the University of Benin Teaching Hospital. Niger J Clin Pract. 2013 Oct-Dec; 16(4):448-53.

11. Varma V, Sogani S, Sarkar PD. Comparative study of serum calcium and magnesium in pre-eclamptic pregnancies in third trimester and its comparison with healthy normotensive non pregnant and pregnant women and to evaluate their role in pregnancy induced hypertension. MGM Med Sci. 2015; 2(3):137-41.

12. Bringman J, Gibbs C, Ahokas R, Syamal B, Ramsey $R$, Egerman $R$. Differences in serum calcium and magnesium between gravidas with severe preeclampsia and normotensive controls. 2006; 19(6): S148

13. Kar M. Role of biomarkers in early detection of preeclampsia. J Clin Diagn Res. 2014 Apr; 8(4):BE01-4

14. Maynard SE, Karumanchi SA. Angiogenic factors and preeclampsia. Semin Nephrol. 2011; 31(1):33-46.

15. Zakiyah N, Postma MJ, Baker PN, van Asselt AD. Pre-eclampsia diagnosis and treatment options: A review of published economic assessments. Pharmacoeconomics. 2015; 33:1069-82.

16. Jain S, Sharma P, Kulshreshtha $S$, Mohan G, Singh $S$. The Role of calcium, magnesium and zinc in preeclampsia. Biol Trace Elem Res. 2010 Feb; 133(2):162-70.

17. Hofmeyr GJ, Lawrie TA, Atallah AN, Duley L, Torloni MR. Calcium supplementation during pregnancy for preventing hypertensive disorders and related problems. Cochrane Database Syst Rev. 2014 Jun 24; (6):CD001059.

18. Malas NO, Shurideh ZM. Does serum calcium in preeclampsia and normal pregnancy differ? Saudi Med J. 2001 Oct; 22(10):868-71. 
19. Kanagal DV, Rajesh A, Rao K, Devi UH, Shetty H, Kumari $S$, et al. Levels of serum calcium and magnesium in pre-eclamptic and normal pregnancy: A study from coastal India. J Clin Diagn Res. 2014; 8(7):OC01-OC04.

20. Deshpande H G, Madkar C S, Bobe A, Nene V. Comparative study of serum calcium and serum magnesium levels in patients of preeclampsia and normotensive patients. Indian J Obstet Gynecol Res. 2018; 5(4):465-70

21. Elmugabil A, Hamdan $H Z$, Elsheikh AE, Rayis DA, Adam I, Gasim Gl. Serum calcium, magnesium, zinc and copper levels in Sudanese women with preeclampsia. PLoS One. 2016; 11(12):e0167495.
22. Owusu Darkwa E, Antwi-Boasiako C, Djagbletey R, Owoo C, Obed S, Sottie D. Serum magnesium and calcium in preeclampsia: A comparative study at the Korle-Bu Teaching Hospital, Ghana. Integr Blood Press Control. 2017 Aug 16; 10:9-15.

23. Ugwuja El, Famurewa $\mathrm{AC}$, Ikaraoha $\mathrm{Cl}$. Comparison of serum calcium and magnesium between preeclamptic and normotensive pregnant nigerian women in Abakaliki, Nigeria. Ann Med Health Sci Res. 2016; 6(1):33-7.

24. Onyegbule OA, Meludu SC, Dioka CE, Udigwe GO, Udo $\mathrm{JN}$, Ezidighoh AN, et al. Comparison of serum levels of calcium and magnesium among preeclamptics and normotensive pregnant women at Nnamdi Azikiwe University Teaching Hospital, Nnewi, Nigeria. Int J Res Med Sci. 2014; 2:404-8.

\begin{tabular}{|c|l|l|l|}
\hline \multicolumn{3}{|c|}{ AUTHORSHIP } & AND CONTRIBUTION DECLARATION \\
\hline Sr. \# & Author(s) Full Name & \multicolumn{1}{|c|}{ Contribution to the paper } & Author(s) Signature \\
\hline 1 & Farheen Aslam & $\begin{array}{l}\text { Data analysis and interpretation, } \\
\text { write up. } \\
\text { Conceptualization of study design, } \\
\text { Final approval of version to be } \\
\text { published. } \\
\text { Data collection, Data analysis. }\end{array}$ \\
\hline 3 & Irum Hayat & $\begin{array}{l}\text { Faizan Ahmad Zakir } \\
\text { Literature search, }\end{array}$ \\
\hline 5 & Shams-Un- Nisa & $\begin{array}{l}\text { Conceptualization of study deisgn. } \\
\text { Data collection, Data analysis. }\end{array}$ \\
\hline 6 & Sadaf Un Nisa & Sata analysis and interpretation. \\
\hline
\end{tabular}

